\title{
Antioxidant activity, total phenolic, and total flavonoid of extracts from the stems of Jasminum nervosum Lour
}

\author{
By Lini Huo, ${ }^{\text {a* }}$ Rumei Lu, ${ }^{a}$ Peiyuan Li, ${ }^{a}$ Yanfang Liao, ${ }^{b}$ Rui Chen, ${ }^{c}$ \\ Chaocheng Deng, ${ }^{a}$ Chengsheng Lu, ${ }^{a}$ Xiangyong Wei ${ }^{a}$ and Yaohua Li ${ }^{a}$ \\ ${ }^{a}$ College of Pharmacy, Guangxi Traditional Chinese Medical University, Nanning, China. \\ ${ }^{\mathrm{b}}$ Guangxi Research Institute of Chemical Industry, Nanning, China \\ ${ }^{c}$ Guangxi Grain and Oil Scientific Institute, Nanning, China \\ ( ${ }^{\star}$ Corresponding author: huolini @ 126.com)
}

\section{RESUMEN}

Actividad antioxidante, fenoles totales y flavonoides totales en extractos de tallos de Jasminum nervosum Lour.

Este estudio evaluó las actividades antioxidantes de extractos de tallos de Jasminum nervosum Lour., y el efecto de diferentes disolventes de extracción en los fenoles totales (TP) y flavonoides totales (TF), y su potencial antioxidante. La actividad antioxidante de los extractos fue evaluada usando los siguientes métodos: DPPH, $\mathrm{ABTS}^{+}$y ensayos reductores. TP y TF fueron detectados por métodos espectroscópicos y por HPLC. Con el primer método, el contenido más alto de TP se obtuvo en el extracto con acetato de etilo (EAE), expresado como equivalentes de ácido gálico. Por su parte, el mayor contenido de TF se obtuvo en el extracto con n-butanol (BE), expresado como equivalentes de luteína. No se observaron diferencias significativas en la relación TP/TF entre los dos extractos. La actividad antioxidante y la relación TP/TF de los tres extractos parecen seguir el mismo comportamiento. Esto implica que hay una buena correlación entre las actividades antioxidantes y la relación TP/TF. Con el método de HPLC, el extracto EAE contenía los más altos contenidos de luteína y ácido gálico, que decrecieron en el mismo orden de EAE $>B E>P E$, el orden de la relación TP/TF de EAE y BE fueron diferentes de acuerdo a su capacidad antioxidante. En conjunto, los resultados muestran que los extractos de EAE y de BE fueron más ricos en compuestos fenólicos y flavonoides que el extracto de éter (PE), y pueden representar una buena fuente de antioxidantes.

PALABRAS-CLAVE: Actividad antioxidante - Atrapadores de radicales libres - Fenoles totales and Flavonoides totales - HPLC - Jasminum nervosum Lour.

\section{SUMMARY}

Antioxidant activity, total phenolic, and total flavonoid of extracts from stems of Jasminum nervosum Lour.

This study evaluated the antioxidant activities of the extracts of Jasminum nervosum Lour. stems along with the effects of different extract solvents on total phenolics (TP), total flavonoids (TF), and antioxidant potential. The antioxidant activity of the extracts was assessed using the following methods: DPPH, $\mathrm{ABTS}^{+}$both free radicals scavenging assays, and reducing assays. TP and TF were detected by spectrophotometric and HPLC methods. In former methods, the highest amount of TP content was ethyl acetate extract (EAE), expressed as gallic acid equivalents. The greatest TF content was in the n-butanol extract (BE), expressed as lutin equivalents. No significant difference was observed in the TP/TF content between these two extracts. The antioxidant activity and TP/TF content of three extracts seemed to follow the same trend. This implied that there is a good correlation between antioxidant activities and TP/TF content. But in HPLC methods, EAE contained the highest content of lutin and gallic acid, which decreased in the same order of $E A E>B E>P E$, the rank order of TP/TF content of $E A E$ and $B E$ were different according to antioxidant ability. The overall results showed that the EAE and BE were richer in phenolics and flavonoids than petroleum ether extract (PE), and may represent a good source of antioxidants.

KEY-WORDS: Antioxidant activity - Free radical scavenger - HPLC - Jasminum nervosum Lour - Total flavaonoid and total phenolic.

\section{INTRODUCTION}

Reactive oxygen species (ROS) are major free radicals generated in many redox processes, which may induce some damage to the human body. Increased production of various forms of activated oxygen species, such as oxygen radicals and nonfree radical species is considered to be the main contributor to oxidative stress, which has been linked to several diseases like atherosclerosis, Parkinson's disease, Alzheimer's disease, stroke, arthritis, chronic inflammatory diseases, cancers, and other degenerative diseases (Halliwell and Grootveld, 1987; McDermott, 2000).

Antioxidants are vital substances which possess the ability to protect the body from damage caused by free radical induced oxidative stress (Ozsoy et al., 2008). Synthetic antioxidants, such as butylated hydroxytoluene $(\mathrm{BHT})$ and butylated hydroxyanisole (BHA), are commonly used in processed foods; these compounds have been reported to cause DNA damage induction and are carcinogenic (Sasaki et al., 2002; Ku and Mun, 2007). Therefore, the search for natural antioxidants that may be used in foods to replace synthetic antioxidants is necessary. Within the antioxidant compounds, flavonoids and phenolics with a large distribution in nature have been studied $(\mathrm{Li}$ 
et al., 2009). In a study by Bushra, fruit peel extracts exhibited high TP, TF, flavonol and scavenging power (2008). It is reported that the wild edible plants in the Black Sea Region of Turkey have strong antioxidant power due to their high concentrations of total phenolic compounds, flavonoids and anthocyanins (Tevfik, 2010). Phenolics or polyphenols, including flavonoids, have received considerable attention because of their physiological functions such as antioxidant, antimutagenic and antitumor activities (Othman et al., 2007). Mohammad et al. also explicitly demonstrated that pharmacological effects may be attributed, at least in part, to the presence of phenols and flavonoids in the extracts (2010). The compounds such as quercetin, rutin, narigin, catechins, caffeic acid, gallic acid and chlorogenic acid, are very important plant constituents because of their antioxidant activities (Paganga et al., 1999), which are also used widly as standard substances today.

Jasminum nervosum Lour. belonging to the Oleaceae family, is a Scandent shrub of $1-5 \mathrm{~m}$ height, found in the Guangdong, Hainan and Guangxi provinces of China. The leaves and the stems are widely used for various applications in traditional medicine, exhibiting a remedy for diarrhea, malaria, sores and ulearations (Editorial committee of the National Chinese Medicine Administrative Bureau. 2005). Some earlier works have been reported on the essential oils, phenylpropanoids, flavonoid and iridoid glycosides of various Jasminum species (Jin W. et al., 2006) which possess good bioactivities such as antioxidant activity, antiviral, antibiosis, antitumour, liver and gallbladder-protection, eliminating pain and relieving spasm, strengthening immunity as well as anti-diabetes and anti-hyperlipidenmia activity, playing significant roles in clinical medicine.

The literature shows that no information exists regarding the use of Jasminum nervosum Lour. stems as a source of natural antioxidants. Therefore, the objectives of this study were to evaluate the stems of Jasminum nervosum Lour. as a source of natural antioxidants using different fractions to determine their antioxidant capacities. Several in vitro assays, including radical-scavenging assays with 1,1-Diphenyl-2-picryl hydrazyl (DPPH), 2,2'-Azobis(3-ethylbenzothiazoline-6-sulfonic acid) (ABTS), and reducing power were carried out to evaluate the antioxidant activity of the extracts from Jasminum nervosum Lour. stems. Because of the important roles of the phenolics and flavonoids as antioxidants, the amounts of total phenolics (TP) and total flavonoids (TF) in the extracts were also determined by spectrophotometric and HPLC methods, expressed as Gallic acid and Lutin equivalents, respectively.

\section{MATERIALS AND METHODS}

\subsection{Chemicals}

1,1-Diphenyl-2-picryl hydrazyl (DPPH) (purity $98 \%$ ) was purchased from Wako Chemicals, Japan;
2,2'-Azobis-(3-ethylbenzothiazoline-6-sulfonic acid) (ABTS) and Butylated hydroxyltoluene (BHT) were purchased from Sigma Aldrich Co., St. Louis, MO, USA; Gallic acid standard and Lutin standard was purchased from J\&K Scientific Ltd., Beijing, China; Acetonitrile (HPLC grade), Methanol (HPLC grade) and Acetic acid (reagent grade) were purchased from Merck\&Co., Inc, Germany; Other chemicals were purchased from China National Medicine Group Shanghai Corporation, Shanghai, China. All chemicals and solvents used were of analytical grade.

\subsection{Preparation of extracts}

Jasminum nervosum Lour. was obtained from the Guangxi Provnice, in August 2009 (summer) before the flowering stage, and authenticated by professor Song Ji Wei, Department of Zhuang Pharmacy, GuangXi traditional Chinese Medical University. The samples were initially air-dried and then reduced to small particles. The particles selected for analysis were passed through a 40-mesh screen and suspended in 95\% ethanol for $48 \mathrm{~h}$ at room temperature. The extracts were concentrated, suspended in deionized water and sequentially partitioned with petroleum ether, ethyl acetate, and $n$-butanol to obtain three different fractions (water part was discarded). Fractions were collected, dried under a rotary evaporator and kept in the dark at $4^{\circ} \mathrm{C}$ until testing. The extract yields with petroleum ether (PE), ethyl acetate (EAE), and $n$-butanol (BE) from the stems of Jasminum nervosum Lour. were $0.71 \%, 0.73 \%$, and $1.87 \%$ $(w / w)$, respectively.

\subsection{Spectrophotometric procedures}

\section{Determination of TP content}

Total soluble phenolics were determined using the Folin-Ciocalteau reagent according to the method of Slinkard and Singleton (1977) and gallic acid as an internal standard. Briefly, the fraction solution $\left(0.5 \mathrm{ml}, 1 \mathrm{mg} \mathrm{ml}^{-1}\right)$ was diluted with distilled water $(46 \mathrm{ml})$ in a volumetric flask. Folin-Ciocalteau reagent $(1 \mathrm{ml})$ was added and mixed thoroughly. After $3 \mathrm{~min}$, a sodium carbonate solution ( $3 \mathrm{ml}, 2 \%$ ) was added and the mixture was allowed to stand for $2 \mathrm{~h}$ with intermittent shaking. The absorbance was measured at $760 \mathrm{~nm}$. The concentration of TP compounds in the extracts was determined as micrograms of Gallic acid equivalent per gram of dry matter. All tests were done in triplicate.

\section{Determination of TF content}

TF content was determined following the procedure by Dewanto et al. (2002), and lutin as an internal standard. A fraction solution $(3 \mathrm{ml}, 0.8 \mathrm{mg}$ $\mathrm{ml}^{-1}$ ) was placed in a 10-ml volumetric flask and 5 $\mathrm{ml}$ of distilled water were added followed by a $\mathrm{NaNO}_{2}$ 
solution $(0.3 \mathrm{ml}, 5 \%)$. After $5 \mathrm{~min}$, an $\mathrm{AlCl}_{3}$ solution $(0.6 \mathrm{ml}, 10 \%)$ was added. After another $5 \mathrm{~min}$, a $\mathrm{NaOH}$ solution ( $2 \mathrm{ml}, 1 \mathrm{M}$ ) was added and the volume was made up with $95 \%$ ethanol. The solution was mixed thoroughly and absorbance was measured at $510 \mathrm{~nm}$. TF amounts were expressed as micrograms of Lutin equivalent per gram of dry matter of extract. All tests were performed in triplicate.

\subsection{High-performance liquid chromatography (HPLC) analysis}

\section{Preparation of standard and sample solutions}

The phenolic and flavonoid compounds in the stem extracts of Jasminum nervosum Lour. were determined by HPLC, performed with a Waters 600 diode array detector system equipped with a dualistic pump. The analyses were carried out on a Diamonsil $\mathrm{C}_{18}$ column (4.6 mm $\left.\times 250 \mathrm{~mm}, 2.5 \mu \mathrm{m}\right)$. Standard stock solutions of Gallic acid and Lutin were prepared in $95 \% \mathrm{EtOH}$, at a concentration of $0.5 \mathrm{mg} \mathrm{m}^{-1}$. All sample solutions of PE, EAE and $B E\left(1 \mathrm{mg} / \mathrm{ml}^{-1}\right)$ were filtered through a $0.45 \mu \mathrm{m}$ membrane filter (Millipore) and injected directly.

\section{HPLC analysis of phenolic compounds}

The mobile phase was composed of sovent $A$ (0.3\% Acetic acid) and sovent B (Acetonitrile). The gradient programme was as follows: (0-5 min, 20\% B; 5-10 min, 90\% B; 10-15 min, 10\% B; 15-25 min, $20 \% \mathrm{~B}$ ); flow rate $1 \mathrm{ml} / \mathrm{min}$; volume injected 20 $\mu \mathrm{l}$; temperature $25^{\circ} \mathrm{C}$; UV detection wavelength 280 $\mathrm{nm}$. All experimental data are expressed as means $\pm S D$ values $(n=3)$

\section{HPLC analysis of flavonoid compounds}

The mobile phase was composed of sovents of $\mathrm{MeOH}$-Water-Acetic acid (40:57.5:2.5) at a flow rate of $1.0 \mathrm{ml} / \mathrm{min}$. The column temperature was set at $25^{\circ} \mathrm{C}$. The injection volume was $20 \mu \mathrm{l}$. The UV detection wavelength was monitored at $254 \mathrm{~nm}$. All experimental data are expressed as means $\pm S D$ values $(n=3)$.

\subsection{Scavenging activity on DPPH radical}

The scavenging effect of different Fractions on the DPPH radical was measured using a modified version of the method described by Shimada et al. (1992). In brief, extract solutions $(20 \mu \mathrm{l})$ in $95 \%$ ethanol at different concentrations $(0.2,0.5,0.8$ and $1.2 \mathrm{mg}$ $\mathrm{ml}^{-1}$ ) were added to $8 \mathrm{ml} 0.0004 \%(\mathrm{w} / \mathrm{v})$ solution of $\mathrm{DPPH}$ in $95 \%$ ethanol. The reaction mixtures were incubated at $28^{\circ} \mathrm{C}$. The scavenging activities on $\mathrm{DPPH}$ radicals were determined by measuring the absorbance at $515 \mathrm{~nm}$ every $10 \mathrm{~min}$ until the reaction reached the steady state. The antioxidant activity was expressed as a percentage of scavenging of $\mathrm{DPPH}$ : SC $\%=[1-($ absorbance of sample)/(absorbance of control)] $\times 100 \%$. The control contains all reagents except the extract. The DPPH radical scavenging activity of BHT $\left(0.5 \mathrm{mg} \mathrm{ml}^{-1}\right)$ was also assayed for comparison. All tests were performed in triplicate and means were centered.

\section{6. $\mathrm{ABTS}^{+} \bullet$ radical cation scavenging}

The antioxidant activities of various solvent extracts in the reaction with the stable $\mathrm{ABTS}^{+}$• radical cation were determined according to the method of Re et al. (1999) with slight modifications. The reaction between ABTS and potassium persulfate directly generates the blue/ green $\mathrm{ABTS}^{+} \bullet$ chromophore, which can be reduced by an antioxidant, thereby resulting in a loss of absorbance at $734 \mathrm{~nm}$. ABTS was dissolved in water to a $7 \mathrm{mM}$ concentration. ABTS radical cation $\left(\mathrm{ABTS}^{+} \bullet\right.$ ) was produced by reacting an ABTS stock solution with $2.45 \mathrm{mM}$ potassium persulfate (final concentration) and allowing the mixture to stand in the dark at room temperature for $12-16 \mathrm{~h}$. The $\mathrm{ABTS}^{+} \bullet$ solution (stable for 2 days) was diluted with a phosphate buffer (2 mM, PH 7.4) to achieve an absorbance of $0.7 \pm 0.05$ at $734 \mathrm{~nm}$. Extract solutions $(10 \mu \mathrm{l})$ were mixed with $\mathrm{ABTS}^{+} \cdot$ solution $(5 \mathrm{ml})$, and absorbance was read at ambient temperature after $1 \mathrm{~min}$. PBS solution was used as a control. All tests were done in triplicate. The radical-scavenging activity of the samples was expressed as SC\% $=\left[\left(A_{\text {control }}-A_{\text {test }}\right) /\right.$ $\left.A_{\text {control }}\right] \times 100 \%$, in which $A_{\text {control }}$ is the absorbance of the control (ABTS ${ }^{+}$- solution without test sample) and $A_{\text {test }}$ is the absorbance of the test sample $\left(\mathrm{ABTS}^{+} \bullet\right.$ solution plus extract). BHT $(0.2,0.5,0.8$ and $1.2 \mathrm{mg} \mathrm{ml}^{-1}$ ) was also assayed for comparison.

\subsection{Reducing power}

The reducing power of Jasminum nervosum Lour. stems was determined according to the method of Oyaizu (1986). Fraction solutions (100 $\mu \mathrm{l})$ in $95 \%$ ethanol $\left(0.2,0.5,0.8\right.$ and $\left.1.2 \mathrm{mg} \mathrm{ml}^{-1}\right)$ were mixed with phosphate buffer $(2.5 \mathrm{ml}, 0.2 \mathrm{M}, \mathrm{pH} 7.4)$ and potassium ferricyanide $\left[\mathrm{K}_{3} \mathrm{Fe}(\mathrm{CN})_{6}\right](2.5 \mathrm{ml}$, $1 \%$ ). The mixture was incubated at $50^{\circ} \mathrm{C}$ for $20 \mathrm{~min}$. A portion $2.5 \mathrm{ml}$ of trichloroacetic acid (10\%) was added to the mixture, which was then centrifuged at $3000 \mathrm{rpm}$ for $10 \mathrm{~min}$. The upper layer of solution (2.5 $\mathrm{ml}$ ) was mixed with distilled water $(2.5 \mathrm{ml})$ and $\mathrm{FeCl}_{3}$ $(0.5 \mathrm{ml}, 0.1 \%)$, and the absorbance was measured at $700 \mathrm{~nm}$. Increased absorbance of the reaction mixture indicated increased reducing power. The reducing power of $\mathrm{BHT}(0.2,0.5,0.8$ and $1.2 \mathrm{mg}$ $\mathrm{ml}^{-1}$ ) were also assayed for comparison.

\section{RESULTS AND DISCESSION}

\subsection{Determined of the TP and TF content by Spectrophotometric procedures}

The total phenolics content (TP) and the total flavonoid content (TF) in the extracts were 
determined from a regression equation for the calibration curve $\left(\mathrm{y}=0.0796 \mathrm{x}+0.0091, \mathrm{R}^{2}=\right.$ $0.9925)$ and $\left(y=0.8836 x-0.0255, R^{2}=0.9998\right)$, respectively. The amount of TP and TF of PE, EAE, and $B E$ are demonstrated in Table 1. EAE revealed the highest total phenolic content at $120.11 \pm 0.42 \mathrm{mg}$ $\mathrm{g}^{-1}$ dry weight, expressed as Gallic acid equivalents, followed by BE and PE. In Addition, BE had the highest flavonoid content $\left(219.22 \pm 1.77 \mathrm{mg} \mathrm{g}^{-1}\right.$ dry weight, expressed as Lutin equivalents) compared to that of other extracts. No significant differences were observed in TP/TF contents between BE and EE. From the introduction, we know that TP and TF content may contribute directly to antioxidant action. Therefore, ethyl acetate and $n$-butanol may be the most effective extracting solvents for antioxidants from the stems of Jasminum nervosum Lour. These results show that the antioxidant activity of extracts of the stems of this plant may be related to their phenolic or flavonoid substrates.

Table 1

TP contents and TF contents in different extracts from the stems of Jasminum nervosum Lour

\begin{tabular}{ccc}
\hline Sample & TP $^{\mathrm{a}}$ & TF $^{\mathrm{b}}$ \\
\hline $\mathrm{PE}$ & $52.00 \pm 2.96$ & $117.14 \pm 3.42$ \\
\hline $\mathrm{EAE}$ & $123.21 \pm 2.82$ & $195.69 \pm 2.83$ \\
\hline $\mathrm{BE}$ & $108.61 \pm 0.31$ & $219.22 \pm 1.77$ \\
\hline
\end{tabular}

Results are mean \pm standard deviation of three parallel measurements. ${ }^{a}$ Milligrams of Gallic acid per $1 \mathrm{~g}$ (dry weight) of extract. ${ }^{b}$ Milligrams of Lutin per $1 \mathrm{~g}$ (dry weight) of extract.

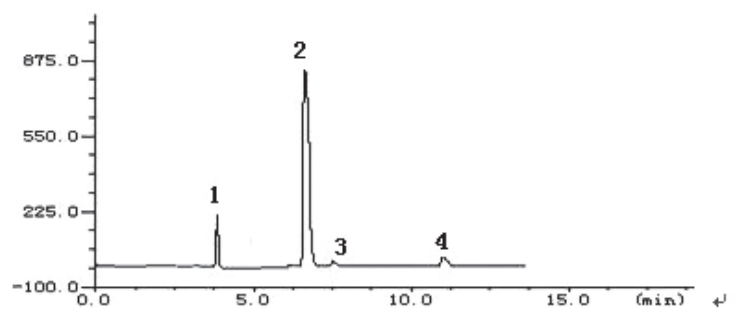

Figure 1

HPLC chromatogram of reference standards (1) Gallic acid, (2) Lutin and (3), (4) unknown residues.

\subsection{Quantitative analyses of Lutin and Gallic acid by HPLC}

RP-HPLC coupled with UV-Vis DAD was employed to separate, identify and quantify phenolic compounds in the fractions of Jasminum nervosum Lour. stems. The concentrations were determined by calculating the HPLC peak areas which are proportional to the amount of analytes in a peak and presented as the mean of three determinations which were highly repeatable. The standard curves for Gallic acid and Lutin were $y=3397.9413+$ $10474.6674 \times\left(R^{2}=0.9905\right)$ and $y=4.8920+$ $16640.1563 \times\left(R^{2}=0.9981\right)$, respectively. Figure 1 shows the chromatogram of reference standards of Gallic acid and Lutin. These compounds have been identified in the PE, EAE, and BE according to their retention times and the spectral characteristics of their peaks against those of standards. As shown in Table 2, EAE contained the highest content of Lutin and Gallic acid. No gallic acid peak was found in PE. By comparing the different fractions, the content of Gallic acid and Lutin decreased in the same order of $E A E>B E>P E$, and the rank order of $E A E$ and $B E$ was different according to their antioxidant pontency and free radical-scavenging ability. This result indicates that, besides Gallic acid and Lutin, the other compounds in Jasminum nervosum Lour. stem extracts may also be responsible for the antioxidant activity. The ethyl acetate solution is more suitable for the extraction of both Gallic acid and Lutin.

Table 2

Contents of Lutin and Gallic acid of different extracts from the stems of Jasminum nervosum Lour. by HPLC

\begin{tabular}{ccc}
\hline Sample & Gallic acid $^{\text {a }}$ & Lutin $^{\text {b }}$ \\
\hline PE & $20.60 \pm 1.02$ & ND \\
\hline EAE & $92.54 \pm 0.59$ & $87.66 \pm 0.88$ \\
\hline BE & $55.26 \pm 0.73$ & $67.42 \pm 1.33$ \\
\hline
\end{tabular}

Results are mean \pm standard deviation of three parallel measurements. ${ }^{\text {a }}$ Milligrams of Gallic acid per $1 \mathrm{~g}$ (dry weight) of extract. ${ }^{\mathrm{b}}$ Milligrams of Lutin per $1 \mathrm{~g}$ (dry weight) of extract. ND, Not detected.

\subsection{Effect of DPPH• scavenging activity}

The scavenging abilities of various extracts against DPPH radical were concentration-dependent, and increased steadily with time (Figure 2). According to the results, PE showed no obvious scavenging activity (Figure 2 A). EAE showed just a little higher antioxidant activity than $\mathrm{BE}$ in this assay system except for the concentration of $1.2 \mathrm{mg} \mathrm{ml}^{-1}$ in BE, which reached the maximum scavenging effect among all the extracts (Figure $2 \mathrm{~B}$ and $\mathrm{C}$ ). The scavenging activities of EAE on the DPPH radical were superior to the positive control, BHT $(0.5 \mathrm{mg}$ $\left.\mathrm{ml}^{-1}\right)$. However, at a low concentration $\left(0.2 \mathrm{mg} \mathrm{ml}^{-1}\right)$, the scavenging activity of EAE was not as effective as $\mathrm{BHT}$ (Figure $2 \mathrm{~B}$ ). Only the scavenging activity of BE at concentration $\left(0.8\right.$ and $\left.1.2 \mathrm{mg} \mathrm{ml}^{-1}\right)$ was better than BHT (Figure $2 \mathrm{C}$ ). It should be noted that $\mathrm{EE}$ and BE have high amounts of TP and TF and also exhibited good DPPH radical scavenging activity.

\subsection{Effect of $A B T S^{+}$escavenging activity}

All extracts tested showed significant ABTS scavenging capacity (Figure 3 ). The control (BHT) and the three fractions exhibited concentrationdependent $\mathrm{ABTS}^{+} \bullet$ scavenging activity. $\mathrm{EAE}$ and $B E$ exhibited similar high scavenging capacity, whereas the lowest activity was found in the PE, which was in accordance with the TP and TF 


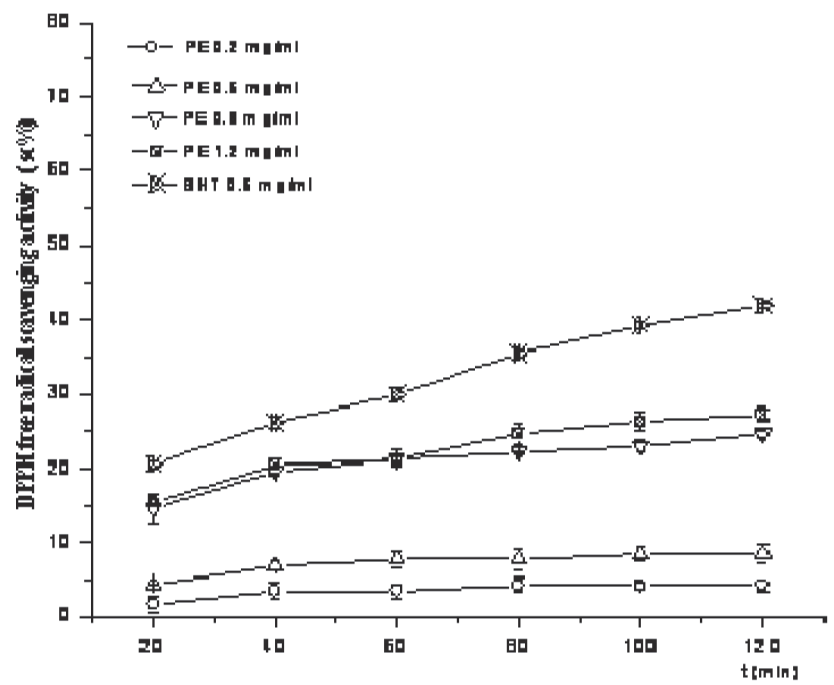

A

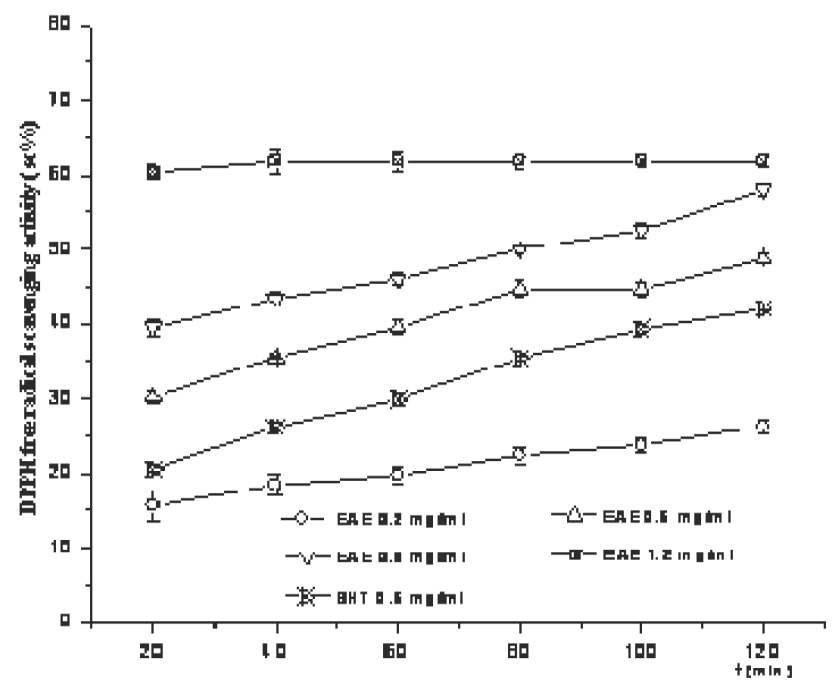

B

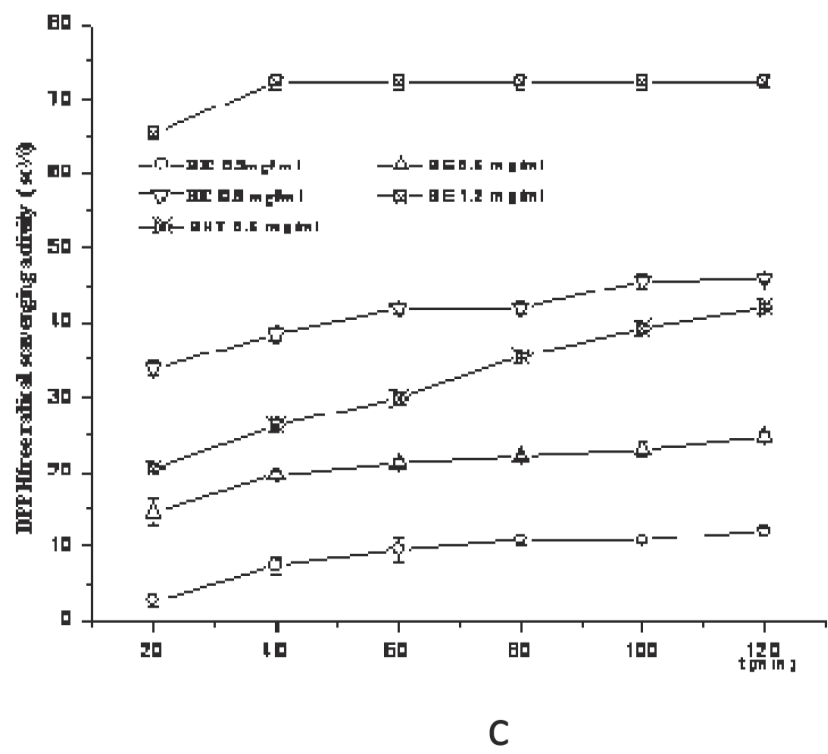

Figure 2

DPPH free radical scavenging activity of $\mathrm{PE}(\mathrm{A}), \mathrm{EAE}(\mathrm{B})$ and $\mathrm{BE}(\mathrm{C})$ from Jasminum nervosum Lour. stems compared with $\mathrm{BHT}$ $\left(0.5 \mathrm{mg} \mathrm{ml}^{-1}\right)$. Results are mean \pm standard deviation of three parallel measurements.

content. The $\mathrm{ABTS}^{+} \bullet$ radical scavenging of EAE and $\mathrm{BE}$ increased rapidly with sample concentration. After $1 \mathrm{~min}$ the scavenging rate could reach $50 \%$ to $95 \%$, but increased slowly at higher concentrations. Under the same experimental conditions, the scavenging activity of the three fractions was lower than the synthetic antioxidant, BHT, but at high concentrations in BE, EAE and BHT, no obvious differences were detected among them.

\subsection{Reducing power}

Figure 4 depicts the reducing properties of each fraction at different concentrations. The results suggest that as electron donors, each extract could convert free radicals into more stable products, leading to the termination of radical chain reactions. Various extracts showed some degree of electron donating capacities in a concentration-dependent manner and BE was the most potent reducing agent. The reducing power of the three fractions was: $\mathrm{BE}>\mathrm{EE}>\mathrm{PE}$. The reductive capability of $B E$ was slightly higher than EE. It is noted that the reducing power of the three fractions was related to the TP and TF contents. Only BE, at low concentrations of $0.2 \mathrm{mg} \mathrm{ml}^{-1}$ and $0.5 \mathrm{mg} \mathrm{ml}^{-1}$, had a stronger reductive capacity than $\mathrm{BHT}$.

\section{CONCLUSIONS}

The highest amount of TP was $123.21 \pm 2.82 \mathrm{mg}$ per gram of dry extract in EAE, while the greatest TF content was $219.22 \pm 1.77 \mathrm{mg}$ per gram of dry extract in BE. The HPLC data indicated that Jasminum nervosum Lour. stems extracts contained phenolic and flavoniod compounds, such as Gallic acid and 


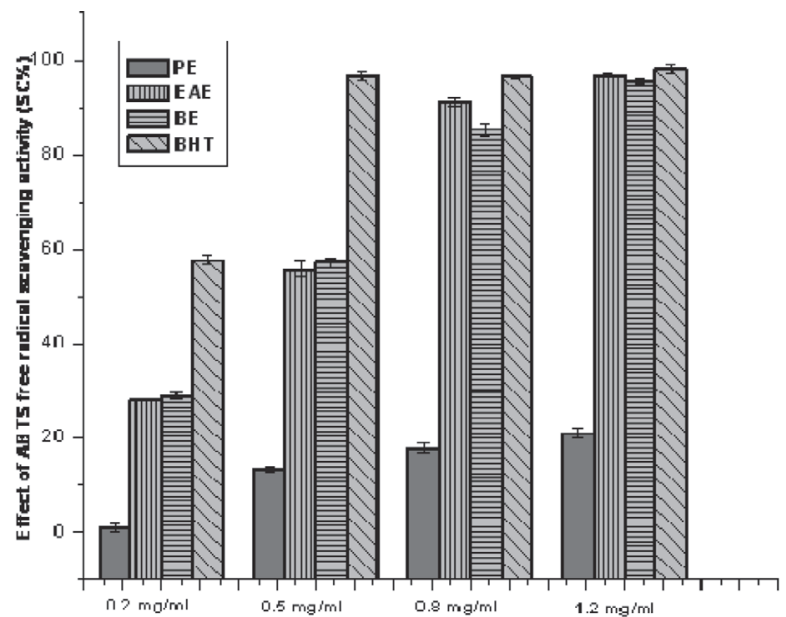

Figure 3

$\mathrm{ABTS}^{+}$free radical scavenging activity of $\mathrm{PE}, \mathrm{EAE}$ and $\mathrm{BE}$ from Jasminum nervosum Lour. stems with BHT as a positive control. Results are mean \pm standard deviation of three parallel measurements.

Lutin, except that there's no Lutin peak found in PE. PE was proved to be the worst part in this plant for antioxidant axtivity as determined by both methods due to its low content of phenolics or flavonoids. The overall results showed that the extracts of Jasminum nervosum Lour. stems exhibited varying degrees of TP/TF contents, and antioxidant activity in vitro and that it can be used as an easily accessible source of natural antioxidants. Future work is advised to provide additional information about the chemical composition of the extracts in order to better understand their mechanism of action as antioxidants.

\section{ACKNOWLEDGMENTS}

This investigation was supported by a grant (P2009035) for subject for Guangxi traditional Chinese Medical University, China.

\section{REFERENCES}

Bushra S, Farooq A, Muhammad RA, Shahzad ASC. 2008. Antioxidant potential of extracts from different agro wastes: Stabilization of corn oil. Grasas $y$ Aceites, 59, 205-217.

Dewanto V, Wu X, Adom K K, Liu R H. 2002. Thermal processing enhances the nutritional value of tomatoes by increasing total antioxidant activity. J. Agric. Food Chem. 50, 3010-3014.

Editorial committee of the National Chinese Medicine Administrative bureau. 2005. Chinese materia medica. Shanghai Scientific and Technical Education Publishing House, Shanghai.

Halliwell B, Grootveld M. 1987. The measurement of free radical reactions in humans. FEBS Lett. 213, 9-14.

Jin W, Jan GF. 2006. Biological activities of iridoids, Herald of Medicine., 25, 530-533.

Li H, Hao Z, Wang X, Huang L, Li J. 2009. Antioxidant activities of extracts and fractions from Lysimachia foenum-graecum Hance. Bioresour Technol. 100, 970-974.

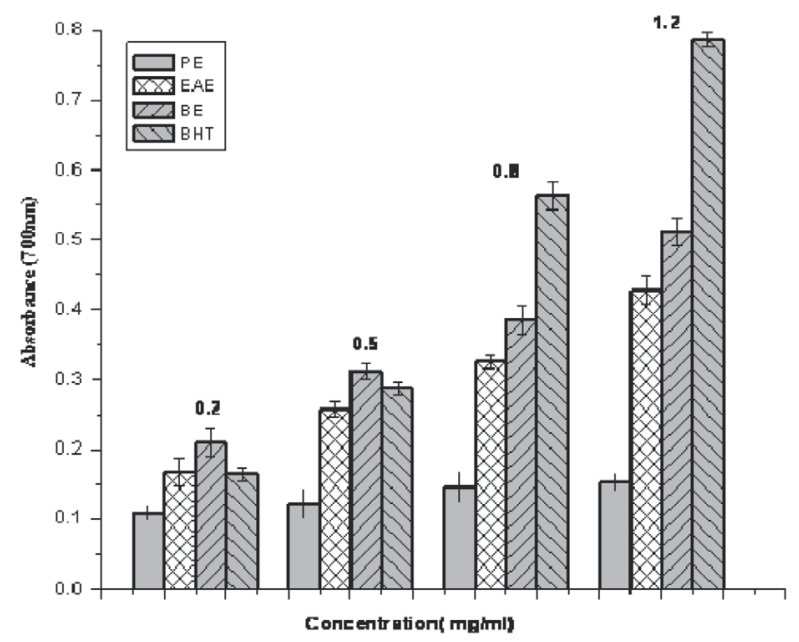

Figure 4

The reducing power of $\mathrm{PE}, \mathrm{EAE}$ and $\mathrm{BE}$ from Jasminum nervosum Lour. stems with BHT as a positive control. Results are mean \pm standard deviation of three parallel measurements.

Ku CS, Mun S P. 2007. Antioxidant activities of ethanol extracts from seeds in fresh Bokbunja (Rubus coreanus Miq.) and wine processing waste. Bioresour Technol. 99, 2852-2856.

McDermott JH. 2000. Antioxidant nutrients: current dietary recommendations and research update. J. Am. Pharm. Assoc. 40, 785-799

Mohammad AE, Seyed FN, Seyed MN, Bahman E. 2010. Antihypoxic and antioxidant activity of Hibiscus esculentus sedes. Grasas y Aceites, 61, 30-36.

Othman A, Ismail A, Ghani AN, Adenan I. 2007. Antioxidant capacity and phenolic content of cocoa beans. Food Chemistry 100, 1523-1530.

Oyaizu M. 1986. Studies on product of browning reaction prepared from glucose amine. Jpn. J. Nutr. 44, 307315.

Ozsoy N, Can A, Yanardag R, Akev N. 2008. Antioxidant activity of Smilax excelsa L. leaf extracts. Food Chemistry 110, 571-583.

Paganga G, Miller N, Rice-Evans CA. 1999. The polyphenolic content of fruit and vegetables and their antioxidant activities. What does a serving constitute?. Free Radical. Res. 30, 153-162.

Re R, Pellegrini N, Proteggente A, Pannala A, Yang M, Rice Evans C. 1999. Antioxidant activity applying an improved ABTS radical cation decolorization assay. Free Radic. Biol. Med. 26, 1231-1237.

Sasak YF, Kawaguchi S, Kamaya A, Ohshita M, Kabasawa K, Iwama K, Taniguchi K, Tsuda S. 2002. The comet assay with 8 mouse organs: Results with 39 currently used food additives. Mutation Research/ Genetic Toxicology and Environmental Mutagenesis. 519, 103-119.

Shimada K, Fujikawa K, Yahara K, Nakamura T. 1992. Antioxidative properties of xanthan on the antioxidation of soybean oil in cyclodextrin emulsion. J. Agric. Food Chem. 40, 945-948.

Slinkard K, Singleton VL. 1977. Total phenol analyses: automation and comparison with manual methods. Am. J. Enol. Vitic. 28, 49-55.

Tevfik Özen. 2010. Antioxidant activity of wild edible plants in the Black Sea Region of Turkey. Grasas y Aceites, 61, 86-94. 